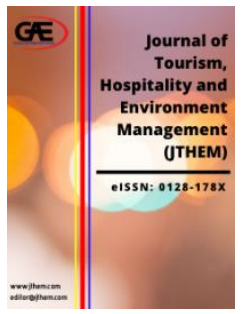

JOURNAL OF TOURISM, HOSPITALITY AND ENVIRONMENT MANAGEMENT (JTHEM)

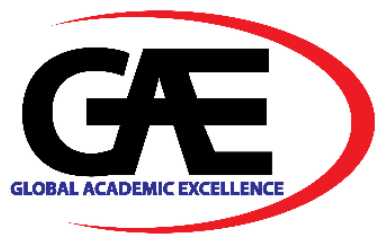

\title{
THE IMPACTS OF INTERNATIONAL GUESTS' EXPERIENCE ON LOYALTY IN HOSTELS
}

Sarinya La-ong-in Thayarnsin ${ }^{1 *}$

1 Department of Hotel Management, School of Tourism and Services, University of the Thai Chamber of Commerce, Thailand

Email: sarinya_lao@utcc.ac.th

* Corresponding Author

\section{Article Info:}

Article history:

Received date: 25.11 .2020

Revised date: 15.12 .2020

Accepted date: 23.12 .2020

Published date: 29.12.2020

\section{To cite this document:}

Thayarnsin, S. L. (2020). The Impacts of International Guests' Experience on Loyalty in Hostels. Journal of Tourism, Hospitality and Environment Management, 5 (21), 224-241.

DOI: $10.35631 /$ JTHEM.5210014.

This work is licensed under $\underline{\text { CC BY } 4.0}$

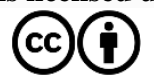

\begin{abstract}
:
Customer loyalty plays a crucial role in the success of hostels in the competitive accommodation business market. This study aims to evaluate the roles of the tourist experience, memory, and image by examining their influences on the process of creating customer loyalty towards the hostels. The study adopts a quantitative approach. This study also draws a comprehensive data set $(\mathrm{N}=445)$ using a convenience sampling approach. The sample was international guests who have experienced in hostels in Bangkok, Thailand. The study employed confirmatory factor analysis and structural equation modelling to achieve the objectives. Findings from the structural analysis indicate a good fit for the proposed model. The findings also reveal that guest experience has significant associations affecting memory which in turn influences loyalty. Subsequently, the guest experience has a positive effect on the image which in turn influences loyalty. Consequently, the guest experience has a significant influence on loyalty. Several implications for theory and practice are discussed in this study.
\end{abstract}

Keywords:

Experience, Image, Loyalty, Hostel

\section{Introduction}

The hostel industry is one of the fastest growing segments of the hospitality industry and also is becoming a more popular alternative than traditional hotels, especially for millennium travelers aged from 18 to 35, as noted by Forbes (2016). As presented by Research and Markets (2020), the demand for hostels in the global market has significantly increased in 2015-2019 and this trend is expected to rise tremendously in the next four years (2020-2024). 


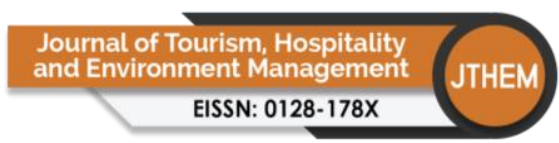

Volume 5 Issue 21 (December 2020) PP. 224-241

DOI 10/35631/JTHEM.5210014

The hostel industry is currently valued at $\$ 5.2$ billion in bed revenue and is forecast to grow by 7-8 percent year-over-year. A large number of people stay at hostels in order to meet people, to make new friends and to listen to others' stories and tips (Verissimo \& Costa, 2018). The core principle of the hostel concept is the surroundings that share beliefs and behavior as well as enhance a feeling of enjoyment with others. Moreover, hotel guests seek out new experiences as well as make social connections. Therefore, it is undeniable that the hostel industry has become one of the dominant segments of the accommodation industry and also focuses on consumers' experience so as to ensure their favorable behavior and loyalty.

Experience has been considered one of the most important predictors of tourists behavioral intention. In the context of tourism, Oh, Fiore and Jeoung (2007) mentioned that the tourist experience refers to everything at a destination that tourists go through such as perception, behavior, emotion and cognition. Similarly, hoteliers have to concern that consumers nowadays spend money on their experiences rather than their material possessions. In addition to this concern for the experience during staying in accommodations including hostels, they should set up an attractive common space and activities to ensure a good perceived experience from hostel guests. Also, they can do enhance their current practices in order to deliver the guest experience. Finally, satisfied hostel guests are a powerful marketing tool in achieving a competitive advantage in a very competitive hostel industry.

The existing research literature on hostels focused on factors influencing loyalty in the accommodation industry. The following factors used in determining loyalty in the literature are service quality (e.g. Alexandris et al., 2002; Juwaheer, 2004; McCain et al., 2005; Tsaur et al., 2002; Malik et al., 2018), perceived value (Nasution \& Mavondo, 2005, Brady et al., 2005; Cronin et al., 2000), customer satisfaction (e.g. Bowen \& Chen, 2001, Han et al., 2008; Kim et al., 2008, Chitty et al., 2007), image (e.g. Ekinci et al., 2008; Kandampully \& Hu, 2007) and involvement (e.g. Back \& Park, 2003, Han et al., 2008) in several context of accommodation such as hotels, youth hostels and casino hotels. However, hostel guest experience is a lack of literature and require further investigation. Also, few studies have tested of these variables including experience, memory and image in a single model of loyalty in the context of hostel industry. This study therefore aims to propose a model describing the relationships between tourist experience, memory and image on consumer loyalty. The study focused on hostels in Bangkok, Thailand which is a highly competitive environment.

The lack of existing research on guests' experience of hostels drove the formulation of the research objectives. The perspective of guests was deemed necessary to gain an overall understanding of the nature of the experience. Thus, stated explicitly this study aims to:

1. investigate relationships among tourist experience, memory, image and consumer loyalty for hostels by proposing and testing a theoretical model and

2. test the mediating impact of memory and image components.

\section{Literature Review}

The hostel industry is one of the fastest growing segments of the hospitality industry. Nowadays, the hostels have changed from the simple and dormitory-style hostels with no amenities in the past to the hostels with chic design and private rooms. This type of 


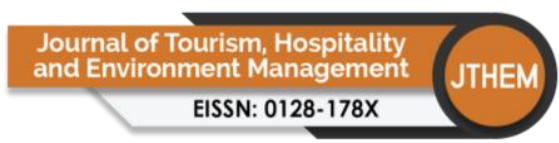

Volume 5 Issue 21 (December 2020) PP. 224-241

DOI 10/35631/JTHEM.5210014

accommodation is drawing guests' attention, especially millennials with fun environments including a common space, coffee bar and areas for cooking or having activities together. According to Southeast Asia hostel market update (C9 Hotelworks, 2018), the growth of hostel market in 2017 rose to $32 \%$ in bed inventory and there are 63,632 beds in 1,766 properties across Southeast Asia. Compared with its prolific tourism numbers in Southeast Asia, Thailand continued to increase its market share with $41 \%$. Moreover, top five hostel market leaders in Southeast Asia are Thailand (25,207 beds in 722 hostels), followed by Malaysia $(9,113$ beds in 263 hostels), Vietnams (7,763 beds in 221 hostels), Cambodia (5,560 beds in 138 hostels) and Singapore (5,541 beds in 92 hostels). Thus, Thailand is the largest sector of the hostel industry in Southeast Asia.

Changing consumer behavior is said to be pervasive in today's society, in other words, people are concerned with engaging experiences rather than with buying goods and services (Postrel, 2003; Richards, 2001). The growth of hospitality sector depends on how to offer distinct and enriched consumer experiences, or the consumption of experiences. Therefore, the first construct used in this study is experience.

Pine and Gilmore (1998) noted that experience refers to a distinct economic that offers to commodities, products and services with a unique, memory and personnel. It is undeniable that tourist experience is not easy to understand and is a complex construct (Neufofer, Buhalis \& Ladkin, 2014). Urry (1990) further explained that the tourist experience is inherently personal. Several ideas of consumer experience have presented in the literature. To start with, Walls et al. (2011) proposed the basis of consumer experience in the hotel and tourism industry. The main four components in the study of Walls et al. (2011) are ordinary, extraordinary, cognitive and emotional experiences. The researchers believe that these four components can help to understand consumer experience in the context of hotel and tourism. Tung and Richie (2011) mentioned that an unforgettable trip in their study consisted of four dimensions of experience including expectation, recollection, affection and consequentiality. In the following year, Kim et al. (2012) stated that the researches related to tourism experience in the literature has great value, however a lack of empirical studies focused on memorable tourism experiences (MTEs). They claimed that MTEs have been considered an important factor influencing behavioral intentions. They also defined MTEs as travel experiences that recall and remember after an event has occurred as well as are constructed based on an individual's assessment. Thus, their study proposed a seven-dimensional MTE scale including hedonism, local culture, knowledge, refreshment, novelty, meaningfulness and involvement. Furthermore, Sfandla \& Bjork (2013) proposed a framework of a tourism experience network based on value line logic by integrating the concepts of companies, consumers, service providers and other main elements. Kim and Ritchie (2014) pointed out that the important dimensions of MTEs include local culture, involvement, refreshment, hedonism, knowledge, novelty and meaningfulness. The study of Tsai (2016) investigated memorable tourist experiences when consuming local food and noted that MTEs are important predictors of tourists' positive behavior. Recently, the study of Sharma and Nayak (2019) confirmed that memorable tourism experiences (MTEs) are designed in order 


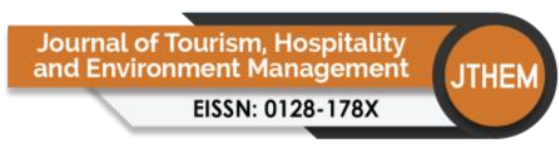

Volume 5 Issue 21 (December 2020) PP. 224-241

DOI 10/35631/JTHEM.5210014

to consolidate and reinforce the recollection of pleasant memories of experiences. Tsai (2016) confirmed that the formation of memorable or unforgettable experiences must lead to sustainable development of tourist destinations.

Although tourist experiences developed from a variety of factors in several previous studies, this study focuses on the study of Pine II and Gilmore (1999, 2011) or Pine and Gilmore's experience economy paradigm (the 4Es). Gilmore and Pine (2002) asserted that this paradigm stands out among applications of the hedonic-experimental view of consumer behavior and suggested that it is appropriate for investigating experiences of tourism products in both hotels and restaurants. Also, other sections in the context of service industry have applied the 4Es in previous studies such as the wine tourism experience (Quadri-Felitti \& Fiore, 2012), the heritage trail experience (Hayes \& MacLeod, 2007), the cruise experience (Hosany \& Witham, 2010), experience in the bed and breakfast setting (Oh et al., 2007) and the special event experience (Pullman \& Gross, 2003). They mentioned that the advent of the experience economy era is the fourth stage of development after the agricultural, industrial and service economies. These experiences are memorable and unforgettable occurrences from consumers. Therefore, this study applied the concept of tourist experience from the study of Pine II and Gilmore proposing four main ideas of experience including aesthetics, entertainment, education and escapism.

Four realms of experience value in the paradigm of experience economy (Pine \& Gilmore, 1999) are aesthetics, entertainment, education and escapism based on the consumers' active and passive participation as well as on absorption or immersion in the experience. Active and passive participation refers to the level of consumer involvement in creation of the experience while absorption is "occupying customers' attention by bringing the experience into the mind" and immersion is "becoming physically or virtually a part of the experience itself" (Pine \& Gilmore, 1999, p. 31). Educational experience refers to consumer increases skills and knowledge through absorbing information presented in an interactive way. In this study, staying at hostels can enhance tourists' knowledge and skills by engaging special events with others such as cooking classes. Another realm is esthetic experience that is defined as consumer enjoys just being in a sensory-rich environment. In other words, tourists are engaged by presenters during their special events when they stay at hostels. Entertainment experience refers to consumer's attention is occupied by the business offering. The other realm is escapist experience referring to consumer as an active actor or participant who shapes events.

Another variable in this study is image. There is a substantial body of empirical and theoretical writing on the topic of importance of image. Image is described in several disciplines including environmental planning, geography, psychology (Echtner \& Ritchie, 1991) marketing and behavioral science (Crompton (1979). Martineau (1958) initially defined image as shopper's mind on functional as well as psychological aspects of store. Echtner \& Ritchie (1991), highly cited researchers, indicated that image is primary concerned with the field of psychology and image can be described as a subset of this much broader field in imagery research. One of the most widely mentioned definitions of image is noted by Keller (1993) defining image as "Perception about a brand as reflected by the brand associations held in consumer memory" $(\mathrm{p}$. 


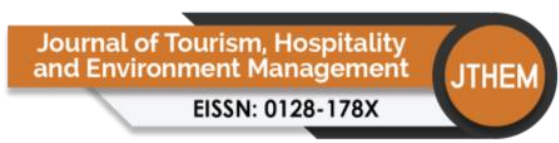

Volume 5 Issue 21 (December 2020) PP. 224-241 DOI 10/35631/JTHEM.5210014

3). However, the majority of previous studies defined destination image as a set of ideas, expectations, emotion thoughts and impressions that a person as toward a specific destination (Kim and Richardson, 2003; Assaker, 2014; Baloglu \& McCleary, 1999; Beerli \& Martin, 2004). Similarly, the study Crompton (1979) is one of the most commonly cited terms of destination image describing as "the sum of beliefs, ideas and impressions that a person has of a destination" (p.18). Related to this study, corporate image has long been recognized as a vital role in the overall evaluation of a business, as noted by Bitner (1990). As mentioned by Keller (1993), brand image has been considered as one of the key factors of marketing research because of its role in building long-term brand equity as well as its role as a foundation for tactical marketing-mix. In the same way, hostel image derived from past experiences has been identified as an important role on tourists' decision making to use a hostel as well as their loyalty. Kim and Kim (2005) assert that brand image in the hotel industry plays a role as a strategy to differentiate from competitors in the competitive environment. Thus, image is made on the minds of consumers when they hear the name of a business (Nguyen, 2006).

The other variable is customer loyalty. Loyalty is regarded as a main key of a business for driving profitable growth (Blackton, 1995). Loyalty is defined as "a biased behavioral response expressed over time by a decision-making unit with respect to one or more alternative brands out of a set of brands and being a function of psychological processes" (Jocoby \& Kyner, p.2). Similarly, loyalty has defined as a characteristic of customers who considered only the same brand as well as repurchased that brand without seeking any information related to it (Newman \& Werbel, 1973). The study of Fornell (1992) revealed that not only repeats purchasing but also willing to spread positive word-of-mouth about a service provider are considered the leading indicators of customer loyalty. Oliver (1999) has defined loyalty as "a deeply held commitment to rebuy or re- patronize a preferred product or service consistently in the future, causing same repetitive brand or same brand-set purchasing, despite situational influences or marketing efforts" (p.31). Later, loyalty is described as a product of repeat purchase, self-stated retention, price insensitivity, resistance to counter-persuasion, and recommendation to others (Jaishankar et al., 2000). Chu (2009) also stated that loyalty is a positive and behavior of customers that promises to repurchase the same brand in the future. Given that the main reason for customer loyalty is the profitability of firms, loyalty refers to the consumers' deep commitment to both products and services, in other words, the customers will continuously repurchase products or services from the same brand. A typical loyal customer will not switch to other brands under the change of market situation as well as the competitive market power, as indicated by Oliver (1997). Therefore, the literature pointed that managers should understand the strategies building customer loyalty in order to hold on existing consumers, motivating them to spend more as well as getting them to recommend products and service to others. Several market researchers assert that customer loyalty can lead to positive outcomes such as a reduction in costs, augmented sales, foreseeable profit flows (Terrill et al., 2000; Ostrowski et al., 1993), increased competitive advantage (Bharadwaj et al., 1993), and is critical to a firm's survival and growth (Reichheld, 1996). 


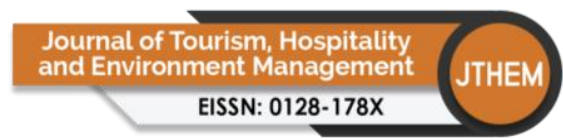

Volume 5 Issue 21 (December 2020) PP. 224-241 DOI 10/35631/JTHEM.5210014

Based on the literature review, the present study included two dimensions of customer loyalty including behavioral and attitudinal loyalty. Behavioral loyalty refers to a behavior that is shown by a consumer to a destination within the form of repeated purchases (Back \& Parks, 2003). The other dimension or attitudinal loyalty is defined as an attitude that is shown by a consumer to a destination within the form of recommending the product/destination to other consumers (Dick \& Basu, 1994; Dimitriades, 2006). To better understand consumer loyalty in terms of intention to revisit in the hostel business leads to increase profitability and to maintain the position of the business. Another perspective of a tourist loyalty to the hostel business is a willingness to recommend if the hostel to others including friends, family, and relatives. International tourist with positive word-of-mouth to others is considered to be an important factor enhancing the image of the hostel and therefore, the growing number of tourists is accounted to that location (Marrocu \& Paci, 2013).

\section{Proposed Conceptual Framework and Hypotheses Development}

The model was used to test the key objectives in this study empirically, as shown in Figure 1. The main interest in this study was to comprehend the intricate associations among millennium guests' experience towards hostels, memory, image and loyalty. A total of five hypotheses was developed to evaluate the proposed model.

Pine and Gilmore (2011) suggested understanding the relationship between experience and memory based on empirical findings should incorporate the 4Es leading to stronger memories. Many previous studies across diverse fields have supported for the significant role of experience in memory formation such as souvenirs (Wilkins, 2011), wine tourism (QuadriFelitti \& Fiore, 2012), theme park (Rajesh \& Srinivas, 2019) and cruise tourism (Hosany \& Witham, 2010). The literature also indicates that experiences are crafted from tourists' traveling in enhancing their positive memories (Kim, 2010; Tung \& Richie, 2011; Oh et al., 2007). In other words, the 4Es were significantly associated with positive memories. In turn, when tourists have positive memories towards somewhere in the past, they tend to revisit or to recommend somewhere to others. Previous studies have examined the impact of memory on loyalty and the findings revealed that tourists' memory of previous trips have had a positive impact on their loyalty (Dick \& Basu, 1994; Lemon \& Wangenheim, 2009; Rajesh \& Srinivas, 2019; Wirtz et al., 2003; Morgan \& Xu, 2009; Lee et al., 2009). In other words, when tourists have positive memories towards somewhere in the past, they tend to revisit or to recommend to others. Several previous studies have examined the impact of memory on consumer loyalty and the finding revealed that if tourists have had a positive memory of previous evidences or trips, they are more likely to revisit or to recommend to others (e.g. Dick \& Basu, 1994; Lemon \& Wangenheim, 2009; Wirtz et al., 2003; Lee et al., 2009; Morgan \& Xu, 2009; Manthiou et al., 2012; Kozak, 2001: Yoon \& Uysal, 2005). Therefore, there is a relationship between experience and memory which in turn leads to consumer loyalty.

Likewise, Chandralal and Valenzuela (2013) investigated the antecedents and behavioral outcomes of memorable tourism experiences (MTEs) from the perspectives of Australian tourists. The finding of this study revealed that memorable tourists influence future intention, 


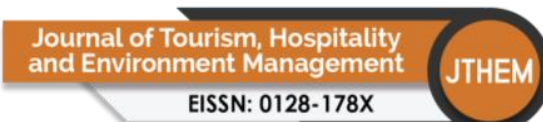

Volume 5 Issue 21 (December 2020) PP. 224-241

DOI 10/35631/JTHEM.5210014

namely intention to recommend to others. Moreover, previous studies have supported the relationship between experience and loyalty (e.g. Cronin \& Taylor, 1992; Tung \& Ritchie, 2011; Woodside et al., 2004; Manthiou et al., 2012; Woodside et al., 2004; Pine \& Gilmore, 2011).

Thus, there is a lack of literature mentioning the relationships among experience, memory and loyalty in the context of accommodation business, especially in hostels. Therefore, based on the empirical findings above, the following hypotheses are posited:

\section{Hypothesis 1: International guests' experience during stay at hostels has a positive and direct effect on their memory}

Hypothesis 2: International guests' memory has a positive and direct effect on their loyalty Hypothesis 3: International guests' experience during their stay at hostels has a positive and direct effect on their loyalty

The relationship between tourist experience and image is scarce in the context of hospitality industry. The present study attempted to test this relationship based on a previous study in the marketing literature. Cleff, Walter and Xie (2018) as well as Kim and Chao (2019) have noted that consumers with brand experience can create deeper emotional connection to a brand leading to improve brand image. Several researchers suggest that consumers' actual experience with products and services can shape the image in consumer mind (e.g. Gronroos, 2000; Lee et al., 2008). Aaker (1996) mentioned that consumer experience with product and services has been recognized as the most influential factor on image. Moreover, hotel guests' experience has been identified as the most influential factor in determining their perceived positive image of the hotel (Kandampully \& Suhartanto, 2000). It can be assumed that if tourists have experience at hostels, they are more likely to perceive a good image of hostels. Thus, the study proposed the following hypothesis.

\section{Hypothesis 4: International guests' experience has a positive and direct effect on their perceived image}

According to Andreassen and Lindestad (1998), an image of firms or organizations plays a vital role in influencing positively and negatively consumer decision and marketing activities. Dhillon (2013) asserted that image is an important variable of a hotel in influencing consumers' perception because of its natural uniqueness including inseparability, tangibility, perishability and heterogeneity. Image is defined as the overall impression that perceived in the mind of the public about something (Mohajerani \& Miremadi, 2012). That means the impression, experience and contacts of the image of service organization can differ from each customer, in other words, people perceived things in different ways. Consumers with good experience during staying in hostels can enhance their perception of hostels' image which in turn leads to their loyalty. Therefore, hostels should realize a high increase of consumer loyalty by managing and controlling service encounters. In addition, they should develop strategies to ensure the entire hostel on supporting to gain positive influence on their image influencing consumer loyalty because the image can improve financial performance, occupancy, business 
esteem, average price, degree of profitability and revenue, as stated by Fung So, King, Sparks and Wang (2013).

Previous studies in the context of service industry mentioned about the relationship between corporate image and consumer loyalty. To start with, the study of Ostrowski et al. (1993) and Norman (1991) demonstrate the positive correlation between the hotel image including location, employee attitude, services and facilities, and consumer loyalty including intention to repurchase and to recommend to others. In 1995, the study revealed that image of luxury hotels leads to consumer satisfaction and consumer loyalty namely consumer preference. In contrast, an undesirable image is associated with consumer dissatisfaction, as mentioned by Mozanec (1995). After that, the researchers from previous studies asserted that the hotel image and consumer satisfaction are main factors in influencing consumer loyalty in terms of intention to repurchase, to recommend and exhibit loyalty (Kandampully \& Suhartanto, 2000). The same authors also stated that "...company image also can be an important element in the value equation...company or brand image can support or undermine the value that customer's feel they are getting, and therefore, image can affect loyalty..." (Suhartanto \& Kandampully, 2003, p. 9). In the following years, the study of Kandampully and $\mathrm{Hu}$ (2007) presented the favorable hotel image is the important factor in determining the customer loyalty. Specifically, the findings of this study revealed that service quality and satisfaction influence the hotel image and in turn this hotel image affects customer loyalty. Finally, several studies recently confirmed the relationship between image and consumer loyalty (Muturi, Jackline Sagwe et al. 2013; Nikou, S., 2016; Nikou, S, Selamat, HB, \& Che, R., 2017). Based on the aforementioned literature, consumer loyalty remarkably improves if the hostel's image is positive. Therefore, tourists with a favorable image towards hostels tend to revisit as well as recommend to others. The following hypothesis is proposed.

Hypothesis 5: International guests' perceived image during their stay at hostels has a positive and direct effect on their loyalty 


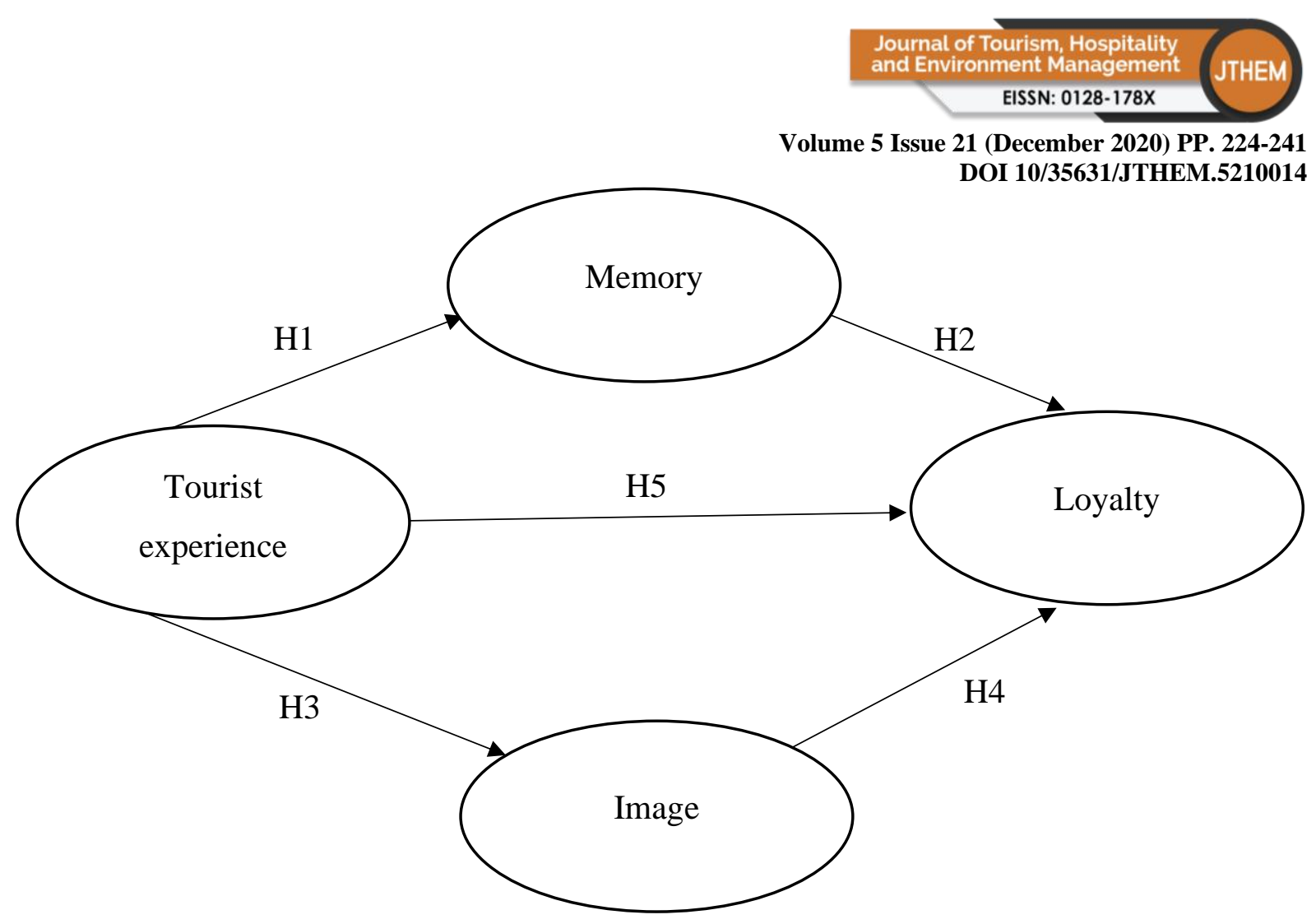

Figure 1: Proposed Model

Source: Adopt by the researcher

\section{Methodology}

\section{Measurement Development}

The survey questionnaires had two major sections including questions to collect demographic information and questions relating to study factor. Also, description of the study provided on the first page of the survey questionnaire. Based on prior studies, the study instrument was developed and employed well-established. The survey instrument consisted of scales measuring tourist experience, hostel image and consumer loyalty. Measures for participants' experience were previously validated from a study of Oh et al. (2007). Specifically, 16 items represented four dimensions of experience including education, entertainment, escapism and aesthetics. A 5-point Likert-type scale from "Extremely disagree"(1) to "Extremely agree" (5) was consistently utilized to measure these study variables. In addition, hostel image was measured using scales developed by Kandampully and Suhartanto (2000). All three scales were measured by means of 5-point Likert-scale items with anchors ranging from (1) Strongly disagree to (5) Strongly agree. Examples of items are "The reputation of this hostel is good", "The overall image of this hostel is good". Finally, loyalty was operationalized by selecting six items from the scale by Zeitham et al. (1996) that are relevant to the study context. Examples of items are "I will remain using this hostel", "I say positive about the hostel to others". This scale was measured by means of a 5-point Likert-type scale with anchors ranging from (1) Strongly disagree (5) Strongly agree. The measurement scales adapted in this study had high applicability in various settings. Also, the author conducted a pre-test with five international tourists, five 


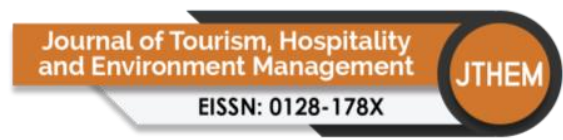

Volume 5 Issue 21 (December 2020) PP. 224-241

DOI 10/35631/JTHEM.5210014

academics in hospitality industry and five industry professionals in order to enhance face and content validity. Therefore, the questionnaire was improved regarding to their feedback.

\section{Data Collection}

The intent of the present study was to investigate international tourists' loyalty towards hostels by integrating the concepts of experience and image. A quantitative approach was used applying a self-administration survey questionnaire with a convenience-sampling approach in the present study. The target population of this study was international travellers who had actually experience in staying in a hostel in Bangkok and also aged 18 years old or over were asked to fill out the questionnaires. The researcher provided a detailed description of the survey to participants and the questionnaires were given as well as retrieved onsite. The participants were received a souvenir after checking for completeness. The total of 1,200 questionnaires were distributed and the 455 questionnaires were returned with 445 usable responses. It indicated about 37.08 percent of response rate.

\section{Respondents' Profiles}

Out of 445 respondents, a majority was males (75.1\%) and aged from 21 to 38, with 29.64 being the average age. In terms of household income, about 51.2\% indicated that their monthly income was between $\$ 1,000$ and 1,$999 ; 35.4 \%, \$ 2,000-2,999$ and $14.3 \%, \$ 999$ or less. The highest proportion of respondents reported being undergraduate-degree holders (57.8\%). Additionally, about $31.5 \%$ indicated being high-school graduates and $10.7 \%$ were postgraduate-degree holders. In terms of their main purpose of traveling to Thailand, there was for vacation 93.6\%. Finally, most participants were from China (53.4\%), America (35.4\%), Singapore (13.4\%) and Canada (3.5\%).

\section{Results}

\section{Evaluation Of Measurement Model}

The skewness and kurtosis values were examined and indicated no major issues regarding to the normality distribution. Thus, these values are appropriate for data analyses. After the preliminary data screening and review of the descriptive statistics, according to Anderson and Gerbing's (1988) two-step approach, a measurement model was estimated a confirmatory factor analysis (CFA) using the maximum likelihood estimation method in order to ensure construct validity and reliability. In short, a measurement model was conducted prior to estimating the structural model. The findings from the CFA indicated that the measurement model satisfactory fit the data well $\left(x^{2}=351.605, \mathrm{df}=160, \mathrm{p}<.001, \mathrm{CFI}=.945, \mathrm{TLI}=.893, \mathrm{NFI}=.945\right.$, RMSEA = .058), as suggested by Hair, Black, Babin and Anderson (2010) and Marsh and Hocevar (1988). Therefore, the measurement model was used for further analyses.

As shown in Table 1, it presents the mean, standard deviation, composite reliability, average variance extracted (AVE), and correlations of each study variable. All standardized factor loadings emerged high and significant. These values indicated the constructs have a good 


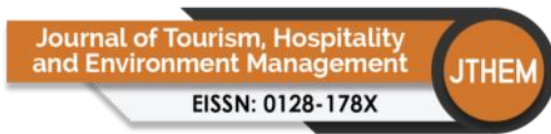

Volume 5 Issue 21 (December 2020) PP. 224-241 DOI 10/35631/JTHEM.5210014

convergent validity (Anderson and Gerbing, 1988). The composite reliability values of all the constructs exceeded the minimum threshold of .70, as suggested by Nunnally (1978). These values indicated that all items for this study are internally consistent and reliable. For the average variance extracted (AVE) values, all constructs were above .50 and the square correlation between any pair of constructs in all cases was less than the AVE of each construct in the pair. As suggested by Fornell and Larcker (1981), it indicated that these values provide good support for discriminant validity of the constructs. Finally, the multicollinearity was checked and a variance inflation factor (VIF) determines how the independent variables are related to one another. The present study presented the VIF values ranging from 1.43 to 1.76 . Therefore, the regression model is acceptable to determine the effect of independent variables on the dependent variables, as suggested by the cutoff threshold of VIF values at 10 (maximum) as the acceptability of multicollinearity (Hair et al., 2006). Thus, these findings showed strong evidence of good reliability and validity of the measures as well as the model fitted the data well leading to proceed to the structural model.

Table 1: Results of the Confirmatory Factor Analysis

\begin{tabular}{lccccc}
\hline & TE & ME & IM & LO & AVE \\
\hline TE & $\mathbf{. 8 5 1}$ & & & & .756 \\
ME & .598 & $\mathbf{. 1 3}$ & & & .738 \\
IM & .413 & .392 & $\mathbf{9 2 1}$ & & .810 \\
LO & .448 & .521 & .412 & .864 & .789 \\
Mean & 4.490 & 4.351 & 4.305 & 4.034 & \\
SD & 1.110 & 1.025 & 1.018 & 1.007 & \\
Cronbach Alpha & .914 & .913 & .904 & .932 & \\
\hline
\end{tabular}

Note: $-\mathrm{N}=445$ Goodness of fit: $x^{2}=351.605(\mathrm{df}=160, \mathrm{p}<.001), \mathrm{CFI}=945, \mathrm{TLI}=.893, \mathrm{NFI}=.945, \mathrm{RMSEA}=.058$

- TE= Tourist Experience; ME=Memory; IM=Image; LO=Loyalty

- Values along the dialogue in bold and italic letters indicate the composite reliability estimate for the scale

Source: Adopt by the researcher

\section{Evaluation of Structural Model and Hypotheses Testing}

The structural model was tested in the following step after the measurement model was appropriate. In this step, assessing the degree of fit to the empirical data was evaluated prior to hypothesis testing. The goodness-of-fit statistics of the proposed model showed that a good model fit $\left(X^{2}=405.778, \mathrm{df}=140, \mathrm{p}<.001, x^{2} \mathrm{df}=2.782, \mathrm{RMSEA}=.079, \mathrm{CFI}=.967, \mathrm{NFI}=.932\right)$. The structural results of the proposed model are depicted in Figure.

The hypothesized relationships were tested and the empirical findings from the SEM were presented in Table 2 and Figure 2. When Hypotheses 1 and 2 were tested, results showed that tourist experience exerted a significant influence on tourists' memory ( $\mathrm{B}=.634, \mathrm{p}<.01$ ) which in turn significantly and positively affected hostel guests' loyalty $(B=.393 \mathrm{p}<.01)$. Therefore, these findings supported Hypotheses 1 and 2. Together, tourist experience accounted for $60.1 \%$ of the total variance in memory. Hypothesis 3 was then evaluated. The result indicated that the 
Volume 5 Issue 21 (December 2020) PP. 224-241 DOI 10/35631/JTHEM.5210014

relationship between tourist experience and hostel guests was significant $(B=.478, \mathrm{p}<.01$ ) and thus Hypothesis 3 was supported. Together, tourist experience accounted for $53.7 \%$ of the total variance in image. Finally, Hypotheses 4 and 5 were assessed and the proposed impact of tourist experience $(\mathrm{B}=.419 \mathrm{p}<.01)$ on image which in turn significantly and positively affected hostel guests' loyalty ( $\mathrm{B}=.296, \mathrm{p}<.01$ ), supporting Hypotheses 4 and 5 . Therefore, tourist experience, memory and image explained about $59.7 \%$ of the variance in loyalty, respectively.

Finally, this study examined the indirect impact of study variables. As presented in Table 2, result found that tourist experience significantly and indirectly affected consumer loyalty (TE$->\mathrm{ME}-->\mathrm{LO}=227, p<.01$ ) through memory. This result indicated that memory acted as a significant mediator. This finding of this study also verified a significant mediating role of image between tourist experience and consumer loyalty (TE --> $\mathrm{IM}$-->LO=.321 $p<.01$ ).

Table 2: Results of the Structural Model

\begin{tabular}{llcc}
\hline Hypotheses & Paths & Coefficients & t-values \\
\hline Hypothesis 1 & TE --> ME & .634 & $8.54^{* *}$ \\
Hypothesis 2 & ME --> LO & .393 & $5.41^{* *}$ \\
Hypothesis 3 & TE --> LO & .478 & $5.63^{* *}$ \\
Hypothesis 4 & TE --> IM & .419 & $6.06^{* *}$ \\
Hypothesis 5 & IM --> LO & .296 & $3.70^{* *}$ \\
Variance explained & & & \\
$\mathrm{R}^{2}(\mathrm{ME})=.607$ & Goodness-of-fit statistics: $x^{2}==405.778, \mathrm{df}=$ & Indirect effect \\
$\mathrm{R}^{2}(\mathrm{IM})=.537$ & 140, p<.001, $x^{2} / \mathrm{df}=2.782, \mathrm{RMSEA}=.079$, & TE-->ME -- \\
& $\mathrm{CFI}=.967, \mathrm{NFI}=.932$ & $>\mathrm{LO}=.227^{* *}$ \\
$\mathrm{R}^{2}(\mathrm{LO})=.597$ & & $\mathrm{TE}-->\mathrm{IM}--$ \\
& & $>\mathrm{LO}=.321^{* *}$ \\
\hline
\end{tabular}

Note: - $\mathrm{N}=445$

- TE=Tourist Experience; ME=Memory; IM=Image; LO=Loyalty

Source: Adopt by the researcher 


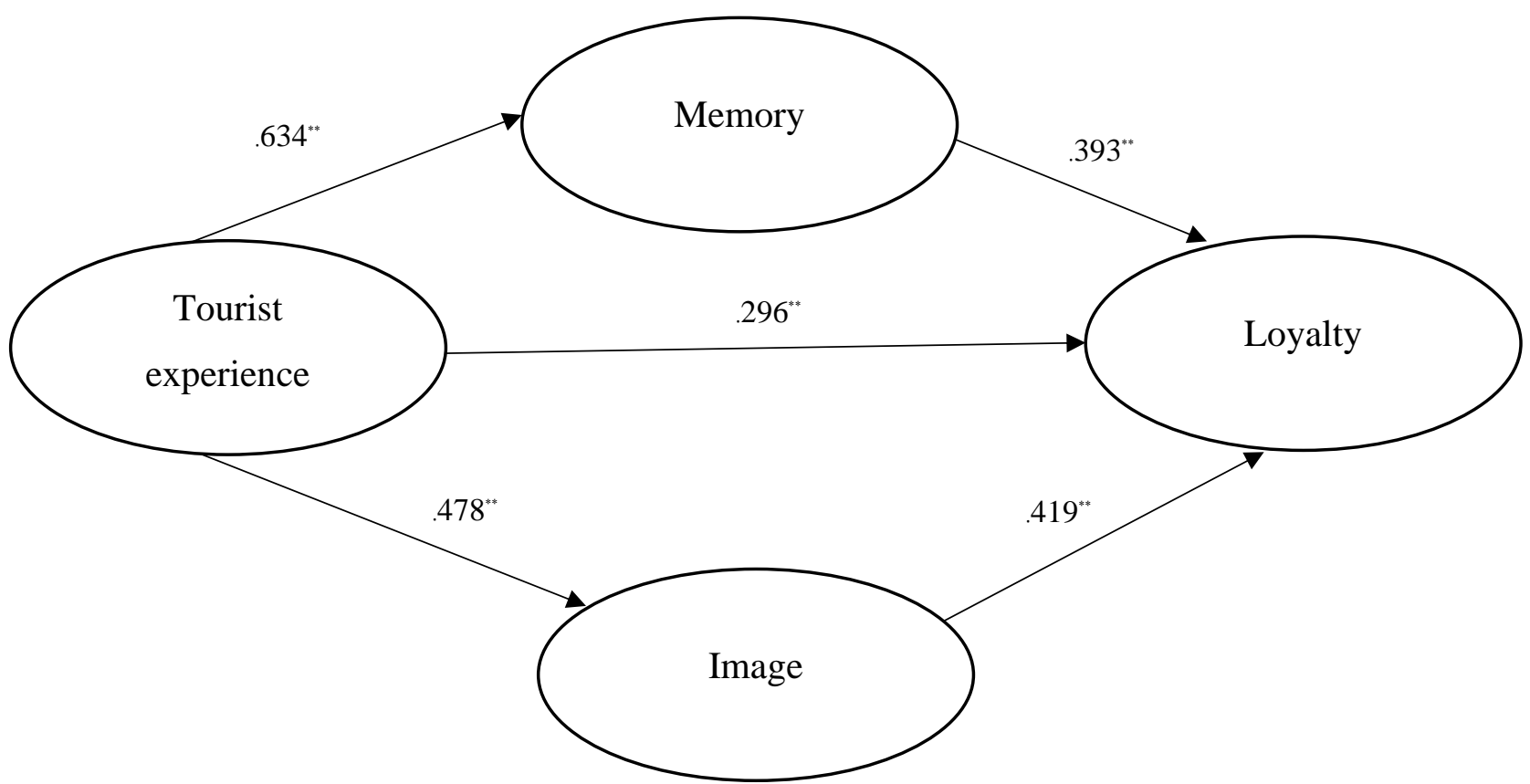

Figure 2: Empirical Model.

Source: Adopt by the researcher

\section{Discussion and Implications}

Despite the significant growth in hostel industry, the limited number of studies integrated the role of experience, memory and image in explaining international guests' post-purchase behavior in hostels. The present study therefore aimed to develop a conceptual model that explicates international travelers' loyalty formation by integrating the impact of experience, memory and image. In addition, this study attempted to examine the mediating role of memory and image components.

The study went on to successfully incorporate experience, memory and image into the conceptual framework describing loyalty formation. Specifically, the model in this study with main key factors has a strong explanatory power for outcome variables, effectively predicting customer loyalty in terms of intention to revisit and intention to recommend the hostel to others $\left(\mathrm{R}^{2}=59.7 \%\right)$. The findings of relationships among study factors in this study provide information for researchers to gain an understanding of international guests' loyalty formation towards hostels and also provide valuable information to develop consumer loyalty strategies.

The findings of this study contribute to the limited literature on accommodation business in several ways. The results revealed that international tourists' experience had a positive impact on their memory which in turn lead to their loyalty towards a hostel. These findings are consistent with previous studies (Wilkins, 2011; Quadri-Felitti \& Fiore, 2012; Hosany \& Witham, 2010). Several researchers pointed that experiences are crafted from tourists' travelling in enhancing their positive memories (e.g. Kim, 2010; Tung \& Richie, 2011). In addition, Oh et al. (2007) stated that travelers with the 4Es were significantly associated with their positive memories and in turn they are willing to revisit as well as recommend the place to others. 


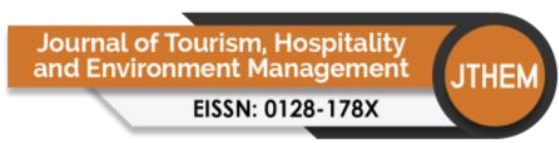

Volume 5 Issue 21 (December 2020) PP. 224-241 DOI 10/35631/JTHEM.5210014

Similarly, many studies have confirmed the relationships between a memory and loyalty, in other words, tourists who have had a positive memory of previous evidences, tend to revisit or to recommend the hostel to others (e.g. Dick \& Basu, 1994; Lemon \& Wangenheim, 2009; Wirtz et al., 2003; Lee et al., 2009; Morgan \& Xu, 2009; Manthiou et al., 2012; Kozak, 2001: Yoon \& Uysal, 2005). Recently, Rajesh and Srinivas (2019) confirmed that service experience significantly influences vivid memory and loyalty. Therefore, the findings of this study confirmed that international tourists' experience had a positive impact on their memories which in turn lead to their loyalty in terms of both intentions to revisit the hostel and to recommend the hostel to others. Moreover, the result of this study provides meaningful insights for hostel managers. It can be confirmed that tourists with positive experiences are the building blocks of future intentions including intention to revisit the hostel and intention to recommend the hostel to others. This study supported previous studies presenting the relationship between experience and loyalty (e.g. Cronin \& Taylor, 1992; Tung \& Ritchie, 2011; Woodside et al., 2004; Manthiou et al., 2012; Woodside et al., 2004; Pine \& Gilmore, 2011). Thus, owners or managers of hostels or accommodation businesses should find ways to improve guests' experience during their stay in his or her property in order to sustain the business in the long term by encouraging their loyalty.

Moreover, this study contributes to the scarcity literature, which has primarily focused on investigating the relationship between experience and image in the context of hospitality industry. The result found the impact of international tourists' experience on their loyalty towards the hostel. The finding is consistent with previous studies in the field of marketing stating that customers who have experience with one brand will lead to deeper emotional connection to the brand improving brand image (Cleff, Walter \& Xie, 2018; Kim \& Chao, 2019). Lee et al. (2008) asserted that consumers' actual experience with products and services can shape the image in their mind. Additionally, hotel guests' experience has been identified as the most influential factor in determining their perceived positive image of the hotel (Kandampully \& Suhartanto, 2000). It can be summarized that hostel guests' experience has a positive impact on their perceived image of hostels. Therefore, the finding of this study can help hostel managers to improve the hostel image by creating a strategic marketing campaign or ways in hopes that it will help to improve the hostel guests' experience.

Finally, the finding of this study contributes to the existing literature in the hospitality industry and the accommodation business. Research on image and customer loyalty is well-established (e.g. Muturi et al., 2013; Kamdampully \& Hu, 2007) but the relationship between image and loyalty has not been significantly addressed by previous studies in the context of hostel industry. This study found significant relationships between image and customer loyalty. In other words, hostel loyal guests are likely to be influenced by the hostel image. The finding is consistent with previous studies in several fields (e.g. Muturi, et al., 2013; Nikou, S, Selamat, HB \& Che, R, 2017). Thus, hostel managers should develop strategies to ensure the entire hostel in order to gain positive influence on the hostel image which in turn leads to customer loyalty. 


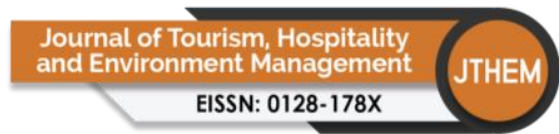

Volume 5 Issue 21 (December 2020) PP. 224-241 DOI 10/35631/JTHEM.5210014

The author aware that the research may have several limitations. First of all, the data were collected in hostels located in Bangkok province, Thailand with a convenience sampling approach. It should be cautious to generalize the findings of a research study to other hostels in other locations. Future research should, therefore, explore in wider of sampling range in order to attain a higher external validity as well as to minimize sampling limitations. Second, the present study assessed the overall experience rather than four dimensions of experience including education, entertainment, escapism and aesthetics. For future research, it should examine in depth the detailed dimensions of experience in order to allow researchers clearly differentiate each dimension of experience in describing international millennium guests' loyalty in hostels. A final limitation is that the study captures only an overall image of hostels in investigating post-behavior of hostel guests. Future research should consider other facets of hostel image in gaining a deeper understanding of hostel guests' loyalty.

\section{References}

Alexandris, K., Dimitriadis, N., \& Markata, D. (2002).Can perceptions of service quality predict behavioral intention? An exploratory study in the hotel sector in Greece. Managing Service Quality, 12(4), 7-19.

Andreassen, T. W.\& Lindestad, B. (1998). Customer loyalty and complex services: The impact of corporate image on quality, customer satisfaction and loyalty for customers with varying degrees of service expertise. International journal of Service industry management, 9(1), 7-23.

Assaker, G. (2014). Examining a hierarchical model of Australia's destination image. Journal of Vacation Marketing, 20(3), 1-16.

Baloglu, S. (1999). A path analytic model of visitation intention involving information sources, socio-psychological motivations, and destination image. Journal of Travel \& Tourism Marketing, 8(3), 81-90.

Beerli, A., \& Martin, J.D. (2004). Factors influencing destination image. International Annals of Tourism Research, 31(3), 657-681.

Brady, M. K., Knight, G. A., Cronin, J.J., Tomas, G., Hult, M., \& Keillor, B. D. (2005). Removing the contextual lens: A multinational, multi-setting comparison of service evaluation models. Journal of Retailing, 81(3), 215-230.

Bowen, J. T., \& Chen, S. (2001). The relationship between customer loyalty and customer satisfaction. International Journal of Hospitality Management, 13(5), 213-217.

Chandralal, L., \& Valenzuela, F. (2013). Exploring Memorable Tourism Experiences: Antecedents and Behavioural Outcomes. Journal of Economics, Business and Management, 12), 177-181.

Chitty, B., Ward, S., \& Chua, C. (2007). An application of the ECSI model as a predictor of satisfaction and loyalty for backpacker hostels. Marketing Intelligence \& Planning, 25, $563-580$

Cleff, T., Walter, N., \& Xie, J. (2018). The effect of online brand experience on brand loyalty: A web of emotions. The IUO Journal of Brand Management, 15(10), 7-24.

Crompton, J. L. (1979). Motivations for Pleasure Vacations. Annals of Tourism Research, 11 (4), 408-424.

Copyright $($ C GLOBAL ACADEMIC EXCELLENCE (M) SDN BHD - All rights reserved 
Cronin, J. J., Brady, M. K., \& Hult, T. M. (2000). Assessing the effects of quality, value, and customer satisfaction on consumer behavioral intentions in service environments. Journal of Retailing, 76(2), 193-218.

Dhillon, D. J. (2013). Brand loyalty in hospitality sector in India: A case study of Indian hotels in Goa-Kerala. Journal of Business and Management, 9(3), 58-63.

Echtner, C. M.\& Ritchie, J.R. (1991). The Meaning and Measurement of Destination Image. Journal of Tourism Studies, 2 (2), 2-12.

Ekinci, Y., Massey, G. R., \& Dawes, P. L. (2008). An extended model of the antecedents and consequences of consumer satisfaction for hospitality services. European Journal of Marketing, 42, 35-68.

Fung So, K. K., King, C., Sparks, B. A., \& Wang, Y. (2013). The influence of customer brand identification on hotel brand evaluation and loyalty department. International Journal of Hospitality Management, 34, 31-41.

Gilmore, J. H., \& Pine, J. (2002). Differentiating hospitality operations via experiences: Why selling services is not enough. Cornell Hotel and Restaurant Administration Quarterly, 43(3), 87-96.

Hayes, D. \& MacLeod, N. (2007). Packaging places: Designing heritage trails using an experience economy perspective to maximize visitor engagement. Journal of Vacation Marketing, 13(1): 45-58.

Hosany S and Witham M (2010). Dimensions of cruisers' experiences, satisfaction, and intention to recommend. Journal of Travel Research, 49(3):351-364.

Juwaheer, T. D. (2004). Exploring international tourists' perceptions of hotel operations by using a modified SERVQUAL approach - a case study of Mauritius. Managing Service Quality, 14, 350-364.

Kandampully, J. \& Hu, H.H. (2007). Do hoteliers need to manage image to retain loyal customers?. International journal of contemporary hospitality management, 19(6), 435 443 .

Kandampully, J. and D. Suhartanto (2000). Customer loyalty in the hotel industry: the role of customer satisfaction and image. International journal of contemporary hospitality management, 12(6), 346-351.

Kandampully, J. \& Suhartanto, D. (2003). The role of customer satisfaction and image in gaining customer loyalty in the hotel industry. Journal of Hospitality \& Leisure Marketing, 10(12), 3-25.

Kim, R.B.\& Chao, Y.(2019). Effects of brand experience, brand image and brand trust on brand building process: The case of Chinese millennial generation consumers. Journal of International Studies, 12(3), 9-21.

Kim, H. \& Richardson, S. L. (2003). Motion picture impacts on destination images. Annals of Tourism Research, 30 (1), 216-237

Malik, S.A., Akhtar, F. \& Raziq, M.M.(2018). Ahmad. Measuring Service Quality Perceptions of Customers in the Hotel Industry of Pakistan. Total Quality Management \& Business Excellence, 5(1), 1-16. 


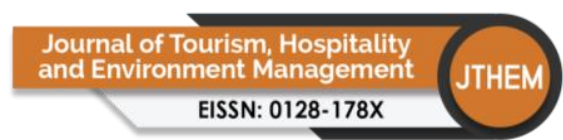

Volume 5 Issue 21 (December 2020) PP. 224-241 DOI 10/35631/JTHEM.5210014

McCain, S. C., Jang, S., \& Hu, C. (2005). Service quality gap analysis toward customer loyalty: Practical guidelines for casino hotels. Hospitality Management, 24, 465-472.

Mohajerani, P., \& Miremadi, A. (2012). Customer satisfaction modeling in hotel industry: A case study of Kish Island in Iran. International Journal of Marketing Studies, 4(3), 134-152.

Morrison, A.M., Pearce, P.L., Moscado, G., Nadkarni, N. \& O'Leary, J.T. (1996). Specialist accommodation: definition, markets served, and roles in tourism development. Journal of Travel Research, 35(1), 18-26.

Muturi, et al. (2013). Determinants of customer loyalty in Kenya: does corporate image play a moderating role?. The TQM Journal, 25(5), 473-491.

Nasution, H. N., \& Mavondo, F. T. (2008). Customer value in the hotel industry: What managers believe they deliver and what customer experience. International Journal of Hospitality Management, 27(2), 204-213.

Neuhofer, B., Buhalis, D. \& Ladkin, A.. (2014) A typology of technology enhanced experiences. International Journal of Tourism Research, 16, 340-350.

Nikou, S., Yusoff, H.S. \& Khiabani, M.M. (2016). Corporate/Hotel Image, Customer Satisfaction, and Customer Loyalty: A Literature Review (1983-2013). International Journal of Research in Management, 6(6), 43-56

Nikou, S, Selamat, HB, Che, R, et al. (2017). Identifying the impact of hotel image on customer loyalty: A case study from four star hotels in Kuala Lumpur. Malaysia. International Journal of Social Science and Economic Research, 2(3), 2786-2810.

Normann, R. (1991). Service Management: Strategy and Leadership in Service Business, Wiley.

Oh, H., Fiore, A.M, \& Jeoung, M. (2007). Measuring experience economy concepts: Tourism applications. Journal of Travel Research, 46(2), 119-132.

Ostrowski, P. L., et al. (1993). Service quality and customer loyalty in the commercial airline industry. Journal of Travel Research, 32(2), 16-24.

Pine II, B.J. \& Gilmore, J.H. (1998). Welcome to the experience economy. Harvard Business Review, 76 (4), 97-105.

Pine, J., \& Gilmore, J.H.(1999). The experience economy: Work is theatre and every business a stage. Boston, MA: Harvard Business School Press.

Postrel, V. (2003). The substance of style. New York: Harper Collins.

Pullman, M. E., \& Gross, M. A. (2003). Welcome to your experience: Where you can check out anytime you'd like, but you can never leave. Journal of Business Management, 9(3), 215 232.

Quadri-Felitti, D.\& Fiore, A.M. (2012). Experience economy constructs as a framework for understanding wine tourism. Journal of Vacation Marketing, 18(1), 3-15

Rajesh, I. \& Srinivas, D. (2019). Role of service experience on vivid memory and loyalty. International Journal of Hospitality and Tourism Administration, 5.

Richards, G. (2001). The experience industry and the creation of attractions. In G. Richards (Ed.). Cultural attractions and European tourism. New York: CABI Publishing, 55-69.

Sfandla, C. \& Bjork, P. (2013). Tourism experience network: Co-creation of experiences in interactive processes. International Journal Tour and Restaurant, 15, 495-506. 
Volume 5 Issue 21 (December 2020) PP. 224-241 DOI 10/35631/JTHEM.5210014

Sharma, P. \& Nayak, J.K. (2019). Understanding memorable tourism experiences as the determinants of tourists' behavior. International Journal Tour and Restaurant, 21, 504 518.

Tsai, C.T.S. (2016). Memorable tourist experiences and place attachment when consuming local food. International Tour and Restaurant, 18, 536-548.

Tsaur, S., Chiu, Y., \& Huang, C. (2002). Determinants of guest loyalty to international tourist hotel-a neural network approach. Tourism Management, 23, 397-405.

Tung, V. W. S. \& Ritchie, J. R. B. (2011). Exploring the essence of memorable tourism experiences.Annals of Tourism Research, 38(4), 1367-1386.

Walls, A., Okumus, F., Wang, R., Youcheng \& Kwun, D.J.W. (2011). Understanding the Consumer Experience: An Exploratory Study of Luxury Hotels. Journal of Hospitality Marketing \& Management, 20(2), 166 - 197.

Wilkins, H. (2011). Souvenirs: What and why we buy. Journal of Travel Research, 50(3): 239_ 247.

Urry, J. (1990). The tourist gaze. London: Sage

Veríssimo, M. \& Costa, C. (2018). Do hostels play a role in pleasing Millennial travellers? The Portuguese case". Journal of Tourism Futures, 4(1), 57-68. 